\title{
SELF-EFFICACY AND CAREER SATISFACTION: THE MEDIATING ROLE OF WORK EFFORT
}

\author{
Julia Yalalova \\ Harbin Institute of Technology, P.R.China \\ Li Zhang \\ Harbin Institute of Technology, P.R.China
}

\begin{abstract}
This study examines whether or not employees' willingness to exert high level of work effort mediates the correlation of self-efficacy and career satisfaction. Another intention is to find if there exist gender differences in self-efficacy, career satisfaction, and work effort. Data were collected from 422 female and male employees of various Russian organizations. The research findings support the idea that employees' willingness to exert a high level of work effort partially mediates the correlation between self-efficacy and career satisfaction. There are also significant gender differences when measuring variables of interest. The article examines the theoretical consequences and suggests recommendations for the future research.
\end{abstract}

Keywords: career satisfaction, gender differences, mediating effect, Russia, self-efficacy, work effort

JEL code: M0, M1

\section{Introduction}

The choice of the Russian Federation as a site for the current research is mainly explained by its long and complex history. For the last 30 years, Russia has experienced many political and economic changes (see Astakhova et al., 2010). During the Union of Soviet Socialist Republics (USSR) period it was the country with the planned economy; many projects had to be coordinated with five-year plans. In 1985 the USSR leader M. Gorbachev had an unsuccessful attempt to loosen social and economic control. As a result, in the world history, the year 1991 was marked as the year of the Soviet Union collapse. Yeltsin's period was renowned for its both lawlessness and political chaos (see Chazan, 2002). But after V. Putin became president many positive changes happened. The improvements in reform and foreign policies raised business confidence in Russia's economic future and increased greatly Foreign Direct Investment (FDI). In fact, the Russian rapid historical development caused the significant changes in the Russian people mindset. 
Over the last two decades many researchers have argued about Russian business culture, as well as its impact on managerial practices (see Ayios, 2005; Hendley et al., 2000; May et al., 2005; Puffer, 1992; Salmi, 1996; Sedaitis, 1998). According to Johnanson (2003) and Kets de Vries et al. (2004), Russian managers tend to bring their companies up to international standards.

In order to develop effective working environment, it is necessary to investigate the specific mechanisms of developing career satisfaction and comprehend the existing gender differences. There are some studies about gender differences in employment and wages in Russia (see Jovanovic and Lokshin, 2004). As Zakirova (2014) emphasizes, every country experiences gender gap, for women, it is more difficult than for men to perform equally in social and economic spheres. In fact, studying the role which gender has on the behavior of employees is very important.

Current study has several purposes: (1) to examine the correlation between self-efficacy, work effort, and career satisfaction, (2) to empirically test the mediation effect of employees' willingness to exert a high level of work effort on the relationship between self-efficacy and career satisfaction, and (3) to study the gender differences in self-efficacy, career satisfaction, and work effort.

This article is structured as follows. Part 2 identifies and classifies such research constructs, as self-efficacy, career satisfaction, work effort, and gender, based on the literature review. Part 3 defines the research design and related methods. Part 4 establishes the questionnaire sampling and statistical analyses. The SPSS software is used for testing the research hypotheses. Part 5 provides with the conclusion and recommendations for the future research.

\section{Literature Review}

\subsection{Self-Efficacy and Career Satisfaction}

Self-efficacy theory of Albert Bandura has become one of the most widely researched topics. It is the personal belief in own abilities to fulfill the task needs and it has an impact on behavioral choices (see Bandura 1977, 1989). Self-efficacy may even result in optimism (see Garcia et al., 2015). Jiang et al. (2013) argue that the learning environment has an impact on personal self-efficacy and goal orientation. Besides, according to the latest studies, self-efficacy has a significant correlation with a specific goal orientation (see Geitz et al., 2016). In overall, self-efficacy affects many variables, including the individual's motivation, job performance, and job satisfaction (see Bandura, 1993).

The research conducted among teachers demonstrates the positive relationship between self-efficacy, self-esteem, and job satisfaction (see Reilly et al., 2014). Job satisfaction is the most popular indicator of overall career quality; people always look for meaningful and challenging jobs that help fulfill their potential (see Shevchuk et al., 2015). The study in 25 Pakistani organizations indicates that learning culture influences the employees' job 
satisfaction (see Sabir and Kalyar, 2013). Jawahar and Stone (2015) proved the partial mediation role of job satisfaction and support on the influence of justice perceptions on organizational citizenship behavior and counterproductive work performance.

H1: There is a significantly positive correlation between self-efficacy, career satisfaction, and work effort.

\subsection{Mediating Role of Work Effort}

The empirical results define that employees' meaning of work has a positive impact on both job engagement and organizational commitment (see Jung and Yoon, 2016). Morris (2009) indicates discretionary work effort regarding the economics and organizational behavior. Levels of work effort and persistence in achieving the purposes despite the existing obstacles are determined by the motivation of the employees (see Jones and George, 2008). Some previous studies suggest a mild, positive relationship between job performance and job satisfaction (see Christen et al., 2006).

Literature regarding the mediating role of work effort and its relationship with career satisfaction has remained relatively limited. There was tested and proved the mediating role of job effort in the relationship between psychological capital and job performance (see Nguyen et al., 2014). Nguni et al. (2006) demonstrate that teachers experiencing high levels of career satisfaction will, in turn, extend extra work effort.

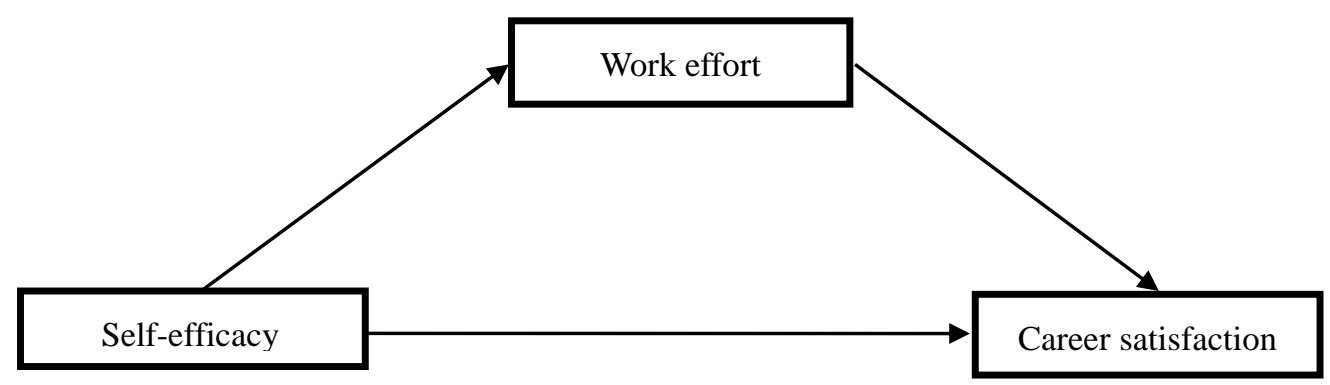

Figure 1. Proposed framework

It is posited that employees' willingness to exert a high level of work effort acts as a mediator of the relationship between self-efficacy and career satisfaction (Figure 1).

H2: Employees' willingness to exert a high level of work effort mediates the relationship between self-efficacy and career satisfaction.

\subsection{Gender Differences}

Gender-specific issues, as well as gender influences, are an emerging field of current studies (see Jennings and Brush, 2013). It is suggested that men and women experience the socialization process oppositely based on differences in expectations, conflicts, and outcomes. The participation in both self-employment and entrepreneurship varies by gender (see 
Saridakis et al., 2014). Nowadays, gender differences lead female employees to adjust the labor time to the needs of their families (see Balleer et al., 2014). In both low and high positions, women have less promotion (see Gobillon et al., 2015).

According to the findings, women are more empathetic and men are more risk-taking and career-focused (see Kirkland et al., 2013; Ferriman et al., 2009). Some earlier studies in sales behaviors show that women are lack of confidence and competitive socialization and experience difficulty in the industrial sales task (see Swan and Futrell, 1978). The sex-role socialization hypothesis assumes women to be less assertive, ambitious, and career oriented than men (see Kaufman and Fetters, 1980). However, Kennedy and Lawton (1992) found a greater job involvement for women than for men, which may reflect the newcomer status of women in sales. In addition, women reported lower satisfaction and lower perceived opportunities for influence in their environments than men did. Xie and Whyte (1997) in their research about gender differences among managers and non-managers found greater differences between male and female non-managers, than between male and female managers.

There have been found significant gender differences in computer skills, security self-efficacy, and prior experience (see Anwar et al., in press). Female employees self-efficacy is lower than this of male employees (see Anwar et al., in press). The study about career satisfaction of academics shows that women are less satisfied with both personal and professional growth, as well as with work-life balance (see Machado-Taylor et al., 2014).

H3: Russian employees of different genders have different reactions to self-efficacy (H3a), work effort (H3b), and career satisfaction (H3c).

\section{Materials and Methods}

The scales were translated from English versions. Self-Efficacy was measured using a ten-item scale developed by Schwarzer and Jerusalem (1995). Work effort was measured using a six-item scale developed by Brown and Leigh (1996). To measure career satisfaction a five-item scale developed by Greenhaus et al. (1990) was used. Participants were asked to evaluate their agreement with the statements using a 7 points Likert scale (from $1=$ very strongly disagree to $7=$ very strongly agree). Respondent's gender was self-reported and coded $1=$ male, 2 = female.

\subsection{Data Analysis Procedure}

The article utilizes survey data collected during May-June, 2016 from 422 employees in different Russian organizations. Respondents were anonymous since the online survey platform was applied to organize and collect the data. The total 500 questionnaires were distributed and 464 questionnaires were submitted back (a $92.8 \%$ response rate). After removing 42 questionnaires because of the missing information, 422 valid questionnaires remained with a balanced ratio of 211 female (50.0\%) and 211 male respondents $(50.0 \%)$. The demographic characteristics of the sample are given in Table 1. Most of the respondents 
are people from 41 to 50 years old, with a total number of 133 participants (31.5\%). Most of the participants are single $(50.2 \%)$ and educated to bachelor's degree level $(55.5 \%)$. The tenure level of the majority is from 1 to 5 years $(46.9 \%)$ and most $(28.2 \%)$ of respondents has an average monthly income of above RUB 80,000.

Table 1. Demographic characteristics

\begin{tabular}{|c|c|c|c|}
\hline Item & Description & Distribution & Percentage $(\%)$ \\
\hline \multirow[t]{2}{*}{ Gender } & Male & 211 & 50.0 \\
\hline & Female & 211 & 50.0 \\
\hline \multirow[t]{6}{*}{ Age } & $18-25$ years & 10 & 2.4 \\
\hline & 26-30 years & 34 & 8.1 \\
\hline & $31-40$ years & 115 & 27.3 \\
\hline & $41-50$ years & 133 & 31.5 \\
\hline & $51-60$ years & 129 & 30.6 \\
\hline & 61 years and above & 1 & 0.2 \\
\hline \multirow[t]{3}{*}{ Marital status } & Single & 212 & 50.2 \\
\hline & Married & 193 & 45.7 \\
\hline & Divorced & 17 & 4.0 \\
\hline \multirow[t]{4}{*}{ Education level } & Matric & 31 & 7.3 \\
\hline & Bachelors & 234 & 55.5 \\
\hline & Master degree & 151 & 35.8 \\
\hline & Ph.D. & 6 & 1.4 \\
\hline \multirow[t]{4}{*}{ Tenure } & $1-5$ years & 198 & 46.9 \\
\hline & 5-10 years & 114 & 27.0 \\
\hline & $10-15$ years & 68 & 16.1 \\
\hline & 15 years and above & 42 & 10.0 \\
\hline \multirow[t]{6}{*}{ Average monthly income (RUB) } & $0-15,000$ & 45 & 10.7 \\
\hline & $15,000-30,000$ & 50 & 11.8 \\
\hline & $30,000-45,000$ & 77 & 18.2 \\
\hline & $45,000-60,000$ & 75 & 17.8 \\
\hline & $60,000-80,000$ & 56 & 13.3 \\
\hline & Above 80,000 & 119 & 28.2 \\
\hline
\end{tabular}

\section{Results}

\subsection{The Correlation between Self-Efficacy, Career Satisfaction, and Work Effort}

The results of the correlation analysis along the means and standard deviations of each variable are presented in Table 2. The top diagonal number of each column of the table indicates the measure of reliability that is Cronbach's alpha for each respective variable. The means and standard deviations for the variables of self-efficacy, career satisfaction, and work effort are 5.4220 (0.78994), 5.6442 (1.02023), and 4.6190 (1.17351) respectively. The correlation analysis shows the significant positive relationship between self-efficacy and 
career satisfaction at $\mathrm{r}=0.486$ and $\mathrm{p}<0.01$. The correlation between self-efficacy and work effort is also positive at $\mathrm{r}=0.316, \mathrm{p}<0.01$. Furthermore, career satisfaction is positively correlated with work effort at $r=0.450, p<0.01$. Thus, hypothesis 1 is supported.

Table 2. Descriptive analysis, correlations and reliability

\begin{tabular}{|l|l|l|l|}
\hline Item & Self-efficacy & Career satisfaction & Work effort \\
\hline Self-efficacy & 0.852 & & \\
\hline Career satisfaction & $0.486^{* *}$ & 0.861 & \\
\hline Work effort & $0.316^{* *}$ & $0.450^{* *}$ & 0.814 \\
\hline Mean & 5.4220 & 5.6442 & 4.6190 \\
\hline Standard deviation & 0.78994 & 1.02023 & 1.17351 \\
\hline
\end{tabular}

\subsection{Work Effort as a Mediator of Relationship between Self-Efficacy and Career Satisfaction}

To become aware of the tools by which self-efficacy predicts career satisfaction, employees' willingness to exert a high level of work effort was tested as a mediator. There was found a support for its partial mediation of this relationship (Table 3). There exists a significantly positive impact of self-efficacy on work effort $(\beta=0.627, t=11.392, p<0.01)$, self-efficacy explains significant proportion of the total variation in work effort $\left(\mathrm{R}^{2}=0.236, \mathrm{~F}=129.771, \mathrm{p}\right.$ $<0.01)$. The analysis of data shows that there is a positive correlation between work effort and career satisfaction $(\beta=0.518, \mathrm{t}=10.332, \mathrm{p}<0.01)$, work effort explains significant proportion of the total variation in career satisfaction $\left(\mathrm{R}^{2}=0.203, \mathrm{~F}=106.758, \mathrm{p}<0.01\right)$. Furthermore, self-efficacy has a positive impact on career satisfaction $(\beta=0.470, t=6.831, p$ $<0.01$ ), self-efficacy explains significant proportion of the total variation in career satisfaction $\left(\mathrm{R}^{2}=0.100, \mathrm{~F}=46.66, \mathrm{p}<0.01\right)$.

\section{Table 3. Mediating role of work effort}

\begin{tabular}{|l|l|l|l|l|l|l|}
\hline Effect & $\mathrm{B}$ & $\mathrm{T}$ & $\mathrm{Sig}$. & $\mathrm{R}^{2}$ & $\mathrm{~F}$ & Sig. \\
\hline Self-efficacy $\rightarrow$ work effort & 0.627 & 11.392 & 0.00 & 0.236 & 129.771 & 0.00 \\
\hline Work effort $\rightarrow$ career satisfaction & 0.518 & 10.332 & 0.00 & 0.203 & 106.758 & 0.00 \\
\hline $\begin{array}{l}\text { Self-efficacy } \\
\text { satisfaction }\end{array}$ & 0.470 & 6.831 & 0.00 & 0.100 & 46.66 & 0.00 \\
\hline $\begin{array}{l}\text { Indirect effect (self-efficacy } \rightarrow \\
\text { work effort } \rightarrow \text { career satisfaction) }\end{array}$ & 0.447 & 7.839 & 0.00 & 0.215 & 57.416 & 0.00 \\
\hline
\end{tabular}

When accounting for work effort, the relationship between self-efficacy and career satisfaction was reduced from $\beta=0.470$ to $\beta=0.447, \mathrm{t}=7.839, \mathrm{p}<0.01, \mathrm{R}^{2}=0.215, \mathrm{~F}=$ $57.416, \mathrm{p}<0.01$. Thus, employees' willingness to exert a high level of work effort mediates the relationship between self-efficacy and career satisfaction. Hypothesis 2 is supported. 


\subsection{Gender Differences in Self-Efficacy, Work Effort, and Career Satisfaction Behaviors}

The results of the t-testing analysis show that average self-efficacy of Russian male employees $(M=5.1697, S D=0.79374)$ is less than those of female employees $(M=5.6744$, $\mathrm{SD}=0.70211)$. Levene's test is $\mathrm{F}=3.147(\mathrm{p}>0.05)$, which didn't meet the significance level. However, the value of $\mathrm{t}(420)=-6.919, \mathrm{p}<0.05$, reached the significance level, indicating that hypothesis $3 \mathrm{a}$ was supported and that the average self-efficacy scores of female employees were greater than those of male employees.

The results of the t-testing analysis show that average willingness to exert a high level of work effort of Russian male employees $(\mathrm{M}=5.4147, \mathrm{SD}=1.03143)$ is less than those of female employees $(M=5.8736, S D=0.95761)$. Levene's test is $F=2.169(p>0.05)$, which didn't meet the significance level. However, the value of $\mathrm{t}(420)=-4.736, \mathrm{p}<0.05$, reached the significance level, indicating that hypothesis $3 \mathrm{~b}$ was supported and that the average work effort scores of female employees were greater than those of male employees.

Table 4. Independent t-test to analyze the gender differences

\begin{tabular}{|l|l|l|l|l|l|l|l|l|}
\hline Variable & Gender & Mean & $\begin{array}{l}\text { Standard } \\
\text { deviation }\end{array}$ & F & Sig. & T & df & Sig. (2-tailed) \\
\hline \multirow{2}{*}{ Self-efficacy } & 1 & 5.1697 & 0.79374 & 3.147 & 0.077 & -6.919 & 420 & 0.000 \\
\cline { 2 - 10 } & 2 & 5.6744 & 0.70211 & & & & & \\
\hline \multirow{2}{*}{ Work effort } & 1 & 5.4147 & 1.03143 & 2.169 & 0.142 & -4.736 & 420 & 0.000 \\
\cline { 2 - 10 } & 2 & 5.8736 & 0.95761 & & & & & 0.002 \\
\hline \multirow{2}{*}{$\begin{array}{l}\text { Career } \\
\text { satisfaction }\end{array}$} & 1 & 4.4464 & 1.22604 & 5.954 & 0.015 & -3.049 & 420 & \\
\cline { 2 - 10 }
\end{tabular}

The results of the t-testing analysis show that average career satisfaction of Russian male employees $(M=4.4464, S D=1.22604)$ is less than those of female employees $(M=4.7915$, $\mathrm{SD}=1.09445)$. Levene's test is $\mathrm{F}=5.954(\mathrm{p}<0.05)$, which reached the level of significance. At the same time the value of $\mathrm{t}(420)=-3.049, \mathrm{p}<0.05$, reached the significance level, indicating that hypothesis $3 \mathrm{c}$ was supported and that the average career satisfaction scores of female employees were greater than those of male employees. The results of t-tests are shown in Table 4.

\section{Conclusions}

Using a questionnaire survey conducted among employees in various organizations of the Russian Federation, there were studied the correlation among all main variables, the mediating role of work effort on the relationship between self-efficacy and career satisfaction, and also there were examined gender differences in self-efficacy, work effort, and career satisfaction. This study offers evidence of how work effort mediates the relationship between self-efficacy and career satisfaction, as well as gender differences existing in self-efficacy, work effort, and career satisfaction. There exists a significant correlation between main 
variables and the average self-efficacy, work effort, and career satisfaction scores of female employees were found to be greater than those of male employees.

Although the relationship between self-efficacy and career satisfaction is frequently studied, the specific tool by which career satisfaction develops has yet to be researched. The research model of this article is a partial mediation model, with work effort being the mediator variable. The Pearson correlation coefficient between self-efficacy and career satisfaction was 0.470 (p $<0.001)$ while with mediator the value was reduced to $0.447(\mathrm{p}<0.001)$. The present study expands on the earlier research by demonstrating the mediating effect of work effort between self-efficacy and career satisfaction among both female and male Russian employees.

\subsection{Applied Implications}

The research is based on responses from Russian employees working in various industries. The findings not only demonstrate the importance of work effort as a mediator in grasping self-efficacy and career satisfaction relationships but also indicate significant gender differences. The independent t-test shows that the average self-efficacy, work effort, and career satisfaction scores of women were greater than those of men. Creating the environment where managers are eager to know the employees satisfaction level and motivation seems to be one of the steps for better management. Although the satisfied employee is not necessarily a productive employee, the satisfied employee is likely to behave better (see Darrat et al., in press). According to Berkery et al. (2013), in order to become successful, organizations need to combine feminine and masculine leadership behaviors.

\subsection{Limitations}

As with any empirical study, this research is not without limitations. One of the limitations has to do with the model of the research. It was hypothesized that work effort mediates the relationship between self-efficacy and career satisfaction. There is a possibility for the future research to test the moderation role of work effort on their relationship.

Another limitation is that only gender differences were observed. Such variables as age, marital status, education level, tenure, or average monthly income can also be taken into consideration when measuring self-efficacy, work effort, and career satisfaction. For instance, Chaudhuri et al. (2015) didn't find the significant impact of age on career satisfaction of female employees.

\subsection{Future Research Directions}

The results of the current study should be of interest to researchers studying the phenomenon of employees' career satisfaction in Russia and in other countries. This article also highlights the need for further analysis of the current situation from different perspectives. This manuscript helps the further investigation into antecedents and consequences of career satisfaction. Despite the further investigation is needed, this research also contributes by 
comparing self-efficacy, work effort, and career satisfaction scores for women and men.

\section{References}

Anwar, M., He, W., Ash, I., Yuan, X., Li, L. and Xu, L. (in press), "Gender difference and employees' cybersecurity behaviors", Computers in Human Behavior.

Astakhova, M., DuBois, C. L. Z. and Hogue, M. (2010), "A typology of middle managers in modern Russia: An intracultural puzzle", International Journal of Intercultural Relations, vol. 34 , no. 5 , pp. 527-539.

Ayios, A. (2005), Trust and Western-Russian business relationships, Aldershot: Ashgate Publishing Limited.

Balleer, A., Gomez-Salvador, R. and Turunen, J. (2014), "Labour force participation across Europe: A cohort-based analysis”, Empirical Economics, vol. 46, no. 4, pp. 1385-1415.

Bandura, A. (1977), "Self-efficacy: Toward a unifying theory of behavioral change", Psychological Review, vol. 84, no. 2, pp. 191-215.

Bandura, A. (1989), "Regulation of cognitive processes through perceived self-efficacy", Developmental Psychology, vol. 25, no. 5, pp. 729-735.

Bandura, A. (1993), "Perceived self-efficacy in cognitive development and functioning", Educational Psychologist, vol. 28, no. 1, pp. 117-148.

Berkery, E., Morley, M. and Tiernan, S. (2013), "Beyond gender role stereotypes and requisite managerial characteristics", Gender in Management, vol. 28, no. 5, pp. 278-298.

Brown, S. P. and Leigh, T. W. (1996), "A new look at psychological climate and its relationship to job involvement, effort, and performance", Journal of Applied Psychology, vol. 81, no. 4, pp. 358-368.

Chaudhuri, K., Reilly, K. T. and Spencer, D. A. (2015), “Job satisfaction, age and tenure: A generalized dynamic random effects model”, Economic Letters, vol. 130, pp. 13-15.

Chazan, G. (2002), Russian revival: A things look up in Moscow, one crucial ingredient remainsmissing: Foreign direct investment, New York: Wall Street Journal.

Christen, M., Iyer, G. and Soberman, D. A. (2006), "Job satisfaction, job performance, and effort: A reexamination using agency theory", Journal of Marketing, vol. 70, no. 1, pp. 137-150. 
Darrat, M. A., Amyx, D. A. and Bennett, R. J. (in press), "Examining the impact of job embeddedness on salesperson deviance: The moderating role of job satisfaction", Industrial Marketing Management.

Ferriman, K., Lubinski, D. and Benbow, C. P. (2009), "Work preferences, life values, and personal views of top math/science graduate students and the profoundly gifted: Developmental changes and sex differences during emerging adulthood and parenthood", Journal of Personality and Social Psychology, vol. 97, no. 3, pp. 517-532.

Garcia, P. R. J. M., Restubog, S. L. D., Bordia, P., Bordia, S. and Roxas, R. E. O. (2015), "Career optimism: The roles of contextual support and career decision-making self-efficacy", Journal of Vocational Behavior, vol. 88, pp. 10-18.

Geitz, G., Brinke, D. J. and Kirschner, P. A. (2016), "Changing learning behavior: Self-efficacy and goal orientation in PBL groups in higher education", International Journal of Educational Research, vol. 75, pp. 146-158.

Gobillon, L., Meurs, D. and Roux, S. (2015), "Estimating gender differences in access to jobs", Journal of Labor Economics, vol. 33, no. 2, pp. 317-363.

Greenhaus, J. H., Parasuraman, S. J. and Wormley, W. H. (1990), "Effects of race on organizational experiences, job performance evaluations, and career outcomes", Academy of Management Journal, vol. 33, no. 1, pp. 64-86.

Hendley, K., Murrell, P. and Ryterman, R. (2000), "Law, relationships and private enforcement: Transactional strategies of Russian enterprises", Europe-Asia Studies, vol. 52, no. 4 , pp. 627-656.

Jawahar, I. M. and Stone, T. H. (2015), "Do career satisfaction and support mediate the effects of justice on organizational citizenship behaviour and counterproductive work behaviour?" Canadian Journal of Administrative Sciences.

Jennings, J. and Brush, C. (2013), Research on women entrepreneurs: Challenges to (and from) the broader entrepreneurship literature? In Greenwood, R. (ed.) Academy of Management Annals, London: Routledge Publishing, pp. 663-717.

Jiang, Y., Song, J., Lee, M. and Bong, M. (2013), "Self-efficacy and achievement goals as motivational links between perceived contexts and achievement", Educational Psychology, vol. 34 , no. 1, pp. 92-117.

Johnanson, M. (2003), “After Russia's unfinished revolution”, Global Finance, vol. 17, no. 4, pp. 22-24. 
Jones, G. R. and George, J. M. (2008), Contemporary management, 5th edition, New York: McGraw-Hill/Irwin.

Jovanovic, B. and Lokshin, M. (2007), "Wage differentials between the state and private sectors in Moscow", Review of Income and Wealth, vol. 50, no. 1, pp. 107-123.

Jung, H. S. and Yoon, H. H. (2016), "What does work meaning to hospitality employees? The effects of meaningful work on employees' organizational commitment: The mediating role of job engagement", International Journal of Hospitality Management, vol. 53, pp. 59-68.

Kaufman, D. and Fetters, M. L. (1980), "Work motivation and job values among professional men and women: A new accounting", Journal of Vocational Behavior, vol. 17, no. 3, pp. 251-262.

Kennedy, E. J. and Lawton, L. (1992), "Men and women in industrial sales: Satisfaction and outcomes", Industrial Marketing Management, vol. 21, pp. 5-14.

Kets de Vries, M., Shekshnia, S., Korotov, K. and Florent-Treacy, E. (2004), "The newglobal Russian business leaders: Lessons froma decade of transition", European Management Journal, vol. 22, pp. 637-648.

Kirkland, R. A., Peterson, E., Baker, C. A., Miller, S. and Pulos, S. (2013), "Meta-analysis reveals adult female superiority in "Reading the mind in the eyes test", North American Journal of Psychology, vol. 15, pp. 121-146.

Machado-Taylor, M. L., White, K. and Gouveia, O. (2014), "Job satisfaction of academics: Does gender matter?” Higher Education Policy, vol. 27, pp. 363-384.

May, R. C., Puffer, S. M. and McCarthy, J. (2005), “Transferring management knowledge to Russia: A culturally based approach", Academy of Management Executive, vol. 19, pp. 24-47.

Morris, R. J. (2009), Employee work motivation and discretionary work effort, Dissertation, Brisbane Graduate School of Business.

Nguni, S., Sleegers, P. and Denessen, E. (2006), "Transformational and transactional leadership effects on teachers' job satisfaction, commitment and organizational citizenship behavior: The Tanzanian case", School Effectiveness and School Improvement, vol. 17, pp. 145-177.

Nguyen, D. T., Nguyen, D. P. and Quan, T. H. M. (2014), "Marketers' psychological capital and performance: The mediating role of quality of work life, job effort and job attractiveness", Asia-Pacific Journal of Business Administration, vol. 6, pp. 36-48. 
Puffer, S. (1992), The Russian management revolution: Preparing managers for market economy, New York: M. E. Sharpe, Inc., Armonk.

Reilly, E., Dhingra, K. and Boduszek, D. (2014), "Teachers' self-efficacy beliefs, self-esteem, and job stress as determinants of job satisfaction", International Journal of Educational Management, vol. 28, pp. 365-378.

Sabir, H. M. and Kalyar, M. N. (2013), "Firm's innovativeness and employee job satisfaction: The role of organizational learning culture", Interdisciplinary Journal of Contemporary Research in Business, vol. 4, pp. 670-686.

Salmi, A. (1996), "Russian networks in transition. Implications for managers", Industrial Marketing Management, vol. 25, pp. 37-45.

Saridakis, G., Marlow, S. and Storey, D. J. (2014), "Do different factors explain male and female self-employment rates?" Journal of Business Venturing, vol. 29, pp. 345-362.

Schwarzer, R. and Jerusalem, M. (1995), "Generalized self-efficacy scale", in Weinman, J., Wright, S. and Johnston, M. (ed.) Measures in health psychology: A user's portfolio. Causal and control beliefs, Windsor: Nfer-Nelson, pp. 35-37.

Sedaitis, J. (1998), "The alliances of spin-offs versus start-ups: Social ties in the genesis of post-soviet alliances”, Organizational Science, vol. 9, pp. 368-381.

Shevchuk, A., Strebkov, D. and Davis, S. N. (2015), "Educational mismatch, gender, and satisfaction in self-employment: The case of Russian-language internet freelancers", Research in Social Stratification and Mobility, vol. 40, pp. 16-28.

Swan, J. E. and Futrell, C. M. (1978), "Men versus women in industrial selling: A performance gap", Industrial Marketing Management, vol. 7, pp. 369-373.

Xie, J. L. and Whyte, G. (1997), “Gender differences among managers and non-managers: An analysis of assessment data", Canadian Journal of Administrative Sciences, vol. 14, no. 3, pp. 340-353.

Zakirova, V. (2014), "Gender inequality in Russia: The perspective of participatory gender budgeting”, Reproductive Health Matters, vol. 22, pp. 202-212. 